\title{
Tnyafar: Women, Livelihoods Strategy Based on Agroforestry (Case Study in Selaru Island, Tanimbar Island District)
}

\author{
Junianita Fridianova Sopamena ${ }^{1, *}$, August Ernst Pattiselanno ${ }^{1}$ \\ ${ }^{I}$ Department of Social Economic, Faculty of Agriculture, Pattimura University, Ambon, Maluku, Indonesia \\ *Corresponding author. Email: junianitasopamena@gmail.com
}

\begin{abstract}
Selaru Island community has long ago been familiar with activity of fulfilling needs through Tnyafar. Being a local wisdom, every household used Tnyafar as a livelihood strategy. Through Tnyafar, community exploited natural resources regularly to ensure the fulfillment of the needs. This research was aimed to analyze community activity that based on local wisdom and to understand the position of local wisdom in the process of fulfilling needs. Research used qualitative approach. Data collection technique involved depth interview and focussed group discussion. Informants were selected with Snowball Technique with land-owner as key informants. Other informants included Tnyafar Chief, Village Chief, and Tnyafar members either men or women. Result of research indicated that Tnyafar was a local wisdom expression in small island that takes into account the limited natural resources as the inheritance for the next generation. Also through Tnyafar, women did work activity together to ensure the fulfillment of needs. All the needs including food, cloth and shelter were fulfilled through the work output at Tnyafar.
\end{abstract}

Keywords: Tnyafar, women, livelihood strategy, agroforestry, small island

\section{INTRODUCTION}

\begin{abstract}
A. Background
The nature has very long ago been the source of income for human, and therefore, human must explore their creativity for the fulfillment of their needs. Women somehow show quite great creativity in processing many sources of food. Even, they look for and exploit their existing natural potentials. Indeed, the nature plays a great role in human's life behavior. Women make medicines and do planting and cultivating the crops. Men go hunting, and thus, have fewer times than women to care their children or even to elaborate their culture local wisdom to their family. Such domestic role is usually done by women.

Women in Selaru Island do many activities in fulfilling the needs of households. The activities never diverge from community habit. Women still comply with the local wisdom insisting on good relationship between human and natural environment in Selaru Island. Women do their activity mostly in Tnyafar. Indeed, they function Tnyafar as shelter, workplace, and room of interaction with community. Women, therefore, have a great contribution to Tnyafar feasibility. It is not surprising because ensuring Tnyafar feasibility
\end{abstract}

would facilitate the fulfillment of the needs of households in sustainable way.

As shown by several studies, such as Mardyaningsih, Tony, \& Dharmawan (2010) [1\}, Widodo (2012)[2], Yulianto (2013)[3], Obeyalu \& Obesile (2015)[4], Chanamuto \& Hall (2015)[5], Mukoni (2015)[6], and Perz (2015)[7], livelihood strategy was closely related with division of role or gender in the family, and local wisdom was important in keeping the sustainability of environment and also of livelihood strategy for fulfilling the needs of households. Although the linkage between livelihood strategy selection and gender-based task division is not yet explained, especially between men and women, but local wisdom is really connected with community's livelihood strategy, community's strategy for the fulfillment of the needs, and gender-based division of task and role.

Studies above indicated different role played by women in the family and society across different communities. Despite this difference, there was a similar view among communities that women play important role in selecting livelihood strategy. Therefore, women must be given a chance to develop their potential in the development, at least not only placing them as the object but also as the subject of the development. They have many roles, including to prepare, provide and create the human 
of development. In domestic role, they prepare children to be a generation with education, dexterity and perseverance. Beyond the house, women interact with community to support the economic of the household. It forces them to master many skills. However, problem behind the development of women resources emerge from a narrow cultural perception that understates women workers' position. This perception prevents women from achieving optimum result. Moreover, previous studies do not reveal clearly how is gender construction built into community, how is the link between gender construction, livelihood strategy, and local wisdom, and what is overload felt by women, families, and communities. Gender construction built by certain community would determine livelihood strategy and local wisdom professed by this community. As a consequence, women are put into prominent or dominant position in the family.

This finding is supported by the Result of Population Census for Year 1990-2010 (BPS, 1990, 2000, 2010) [8] [9] [10] revealing that the percentage point of women as patriarch (WKRT) has been grown. In Indonesia generally, this percentage point increases from $5.86 \%$ in 1990 to $6.20 \%$ in 2000 , and it jumps up to $7.24 \%$ in 2010 . This reality is very attractive spot for analysis. It can be said that slower but sure, women indeed start to replace men as the leader of household through status and occupation they have, but it also overburdens women with greater workload than men.

All processes of fulfilling the needs are signified by Tanimbar community as local wisdom and it still continuous to be applied at Tnyafar, which represents a farming place where it is located not far from the village and used as temporary shelter for farmers and their family. Tnyafar concept provides bigger role to women in family because they can do some activities in domestic and public realms simultaneously (Atsea, 2011; Maspaitella, 2011; Budiani, 2013; Pattiselanno, et.al., 2015)[11][12][13] [14].

\section{B. Objective}

This research is aimed:

1. to analyze women activity that based on local wisdom; and

2. to understand the position of local wisdom in the process of fulfilling the needs of households.

\section{METHOD OF RESEARCH}

\section{A. Qualitative Approach}

This research used a qualitative approach. Main strategy to operate this approach was a case study as suggested by [5][15], [6][16], [7][17], and [8][18]. A case study was used because it was relevant to the articulation of Tnyafar which until today it was still continually professed by the Selaru Island community. The case study also allowed the author and respondents to develop interaction and dialog, as explained by [5][15] and [6][16].

\section{B. Location of Research, Population and Informants of Research}

Selaru Island belonged to the administration area of Selaru Island District, West Southeast Maluku Regency (MTB Regency). Selaru Island was one of few islands in MTB Regency occupied by Tanimbar Ethnic as the native inhabitant. The administrative area in Selaru Island District comprised of five villages. The distinctive marker of the inhabitant was high capacity of migration among Tanimbar Ethnic in Selaru Island. This ethnic could settle on few islands with few inhabitants, and also assimilate easily with community in few villages in the Selaru Island or beyond the island.

Research population was Selaru Island community who conducted Tnyafar. Informants included men and women who occupied Tnyafar. There were 25 informants, and their status were leader, formerleader, and member of Tnyafar. The leadership structure of Tnyafar consisted of Chair, Secretary, and Treasurer. Mostly, treasurer was a woman, but in some Tnyafar, woman worked as secretary. Other Tnyafar even selected woman as the Chair. The Head of Customs was key informant who understood well the working structure and the activity of Tnyafar.

\section{Case Selection, Deep Interview, and Participative Observation}

For obtaining the information, the author asked some questions to the key informant, precisely the Head of Customs as the community figure in Adaut Village in Selaru Island, who regularly conducted Tnyafar local wisdom. Snowball technique as explained by [9] [19] was used to obtain other informants. Deep interview was performed to obtain more relevant informations. Focused Group Discussion was implemented to strengthen information previously obtained. Participative Observation [9] [19] was also conducted because it allowed the author to see, to feel and to sense the world, events, and social symptoms in the way the actor did. It was also helpful to establish mutual understanding between the author and the actor (inter-subjectivity).

\section{Data Analysis}

Mentioned about three paths in analyzing qualitative data. It started with continuous data 
reduction that involved some activities such as selecting, concentrating attention, making simplification and abstraction, and transforming data given by informants. It was followed by data presentation which displayed important information about Tnyafar. The presentation helped the author in preparing the conclusion and next action. Conclusion remark included a verification on the previous conclusion about Tnyafar as local wisdom [10][20].

\section{RESULTS AND DISCUSSION}

\section{Tnyafar Process}

Tnyafar process is related with production output. By such connotation, Tnyafar is a product of various commodities cultivated. Tnyafar process accomodates all crop commodities possible to cultivate, although some farmers may prefer only to cultivate annual plant or just do gardening. Crop commodities they cultivate include rice, peanut, corn and edible tuber. The annual plant involves coconut, cacao and orange. If situation and condition of the nature (especially the sea) are supportive, then Tnyafar members can cultivate sea grass. During Tnyafar process, the cultivated crop can play double roles, respectively being a business commodity and also a subsistence commodity. In the other hand, annual plant and sea grass have one singular function, that is being a business commodity. Besides all these functions, Tnyafar concept also involves functions such as food resilience and life environment conservation. Farming output from Tnyafar was sold by women. The selling activity could take a place in the village or out of the village, and even they go for trading to the capital of Regency.

This is described by the following informant:

What we do in Tnyafar is gardening and catching fish. The crop we are planting in Tnyafar includes corn, rice, edible tuber, taro, cassava, purplish tuber, sweet potato (petatas), banana, coconut, papaya, pare, eggplant, basil, lemongrass, lemonade, turmeric, peanut, red bean, green bean, and water melon. Sea product that giving us income includes fish, sea cucumber, lola, and sea grass. Livetock we breed in Tnyafar includes pig and chicken.

(Depth interview with Mrs. AF, 6 April 2017)

Similar finding is also found in Focussed Group Discussion:

January, we are planting corn, edible tuber, and purplish tuber. But still, people can decide for planting another. Banana and coconut are put aside now. March, we harvest the corn, and wait for the tubers. We give much attention to the tubers. The post-harvested corn land is left fallow. Purplish tubers are harvested on July. Variant of tubers may need 8 to 9 months for harvest. If tubers are seeded on January to February, harvest begins on September. The post-harvest land can still be used for tubers for the next 3 years. After 3 years, farmers shift to the new garden. New stem is taken from the newly harvested tubers. After purplish tubers are rooted up, the stem is replanted on the post-harvested land. We are planting edible tubers from September to October. Edible tubers and purplish tubers are planted and harvested alternately.

After the plot are planted for 3 years, farmers change to the new garden. They may return the very first land after 17-18 years. In new garden, they are planting coconut, along with edible tuber or purplish tuber. When coconut grows higher and gives farmers a harvest, then tubers are no longer giving a promising result. It is said so because coconut is a long-term plant, and tubers must be grown on other location.

(Result of Focussed Group Discussion, 11 June 2017)

As the author observes Focussed Group Discussion, it is found that plants grown in Tnyafar are based on agreement. It is explained as follows:

Farmers as cultivator may decide to plant coconut, but the land still belongs to the landowner. If someone buys the land, the price is not only including the land price owned by landowner, but also entailing coconut cultivated by farmers.

More coconuts the farmers can cultivate, more hamlets they would have. Each landowner always knows the border of their land because their parent give it to them as inheritance. How many coconuts are grown in Tnyafar is information the parent often give to their children. Garden width depends on Tnyafar extent. Rice was ever planted in Tnyafar Kora, and the variant was red and black rices.

Garden is affected by location and width. Two adjacent gardens are usually used. For instance, one group consists of 10 members. The plot is then divided into two squares. New pole is tied in rope and put on into like-rhomboid shape. The size of divided plot is similar. The camomile variant like pateka or water melon cannot be set for land border. The border sign must be visible and conspicuous. It can be burn trace, rope, or stone. The plant to grow in each garden is free.

(Result of Focussed Group Discussion, 11 June 2017)

Based on the explanation above, farming in Tnyafar can be described as following:

1. Coconut is not longer the option because it is already there. The planting of coconut is done only to replace the failed coconut or to substitute for those that must be cut for certain needs. 
2. Corn is harvested on March. Variant of tubers is waiting on schedule. Grower's emphasis is given to these tubers. The post-harvested corn land is not longer feasible for growing.

3. Purplish tubers are harvested on July.

4. After harvesting purplish tubers, the new stem can be stabbed into the post-harvested land.

5. Edible tubers are harvested around August to September.

6. After harvesting edible tubers, it is replanted on post-harvested land.

\section{Agroforestry : Utilization of Garden and Hamlet in Tnyafar}

For the community conducting Tnyafar, hamlet is a treasure (grown with coconuts). Coconut is usually processed into copra and the copra is sold for fulfilling daily needs. For smaller Tnyafar (for instance, 1 hectare width), community hamlet stays adjacently. Small land is worked on to fulfill the needs of 12-18 persons. All community members work together from land opening to planting. When harvest season comes, patriarchs (men) climb coconut trees for the fruits. Coconut is the only commodity utilized by community to meet daily needs. Each family only has 1 hamlet, or no more. Hamlet is acquired from the parent as inheritance to the descendant. However, the direct beneficiary is always the son, and the daughter only inherits her parts after the son decides to give the right of his sister. If the son is not willing to share with his sister, then daughter never inherits part of the hamlet. If the family has only daughters, then distribution is done by the oldest. Daughter is not the priority in allotting inheritance. The community believes that at certain days, daughter would follow her husband after marriage, and they can live with her husband's allotment. It is said so because the married women would release her father's family name, and use her husband's family name.

\section{Tnyafar and Livelihood Strategy Selection by Agroforestry}

Livelihood strategy selected by every household depends on the potential of natural and human resources available. Each household in same Tnyafar may have different livelihood strategy due to different accessibility to natural resource and different human resource skill. At different Tnyafar, different livelihood strategy can be absolutely obvious. Every Tnyafar has its own distinctive marker which may influence the method of how to utilize natural and human resources available. The following informants describe the livelihood strategy developed by different Tnyafar.

A member of Tnyafar Kora, Mr M, explains the livelihood strategy selected by his family as follows:
The specific crops such as cassava (kasbi), purplish tuber, sweet potato (patatas), taro, banana, and long-term plant, such as coconut, are useful for the border sign (sipat) of the land/arin. Garden yields are mainly consumed as family food, but the excess, if any, is sold to the market. The trade may also go on to Adault Village, and if certain commodity is still left, it would be carried to Saumlaki Market.

The decision to go for sale is usually collective agreement (between husband and wife), or is made occasionally because there are needs for child education. If the commodity is not sold, it is brought back to home for consumption.

Wife works at the garden and prepares meals for family.

(Depth Interview with Mr SM, 9 June 2017 in Tnyafar Kora)

Mr and Mrs L have elaborated livelihood strategy selected by their family during their activity in Tnyafar Kora. It is described as follows:

When I come in in December, Sasi has been prevailed for sea products. They collect sea cucumber. They harvest it every year, and it is similar to coconut with three times harvests in a year. Sea products are often subjected to Sasi in December. Government regulates the exploitation of sea products with Sasi involving third-year renewal. For instance, if previous December is allotted for sea cucumber, then current December is opened for lola. People dive not for sea cucumber because it is still juvenile and must be waited for few years to obtain harvest size. The entity applying Sasi for sea products is the government coordinating with local church assembly.

(Depth Interview with Mr and Mrs L, in Tnyafar Kora, Saturday, 18 June 2017)

The selected livelihood strategy is agreed by members of Tnyafar Kora during Focussed Group Discussion. The illustration is given as follows:

Crop planted every year is different. In first year, we have banana, coconut, edible tubers, cassava and purplish tuber. Second year is used for coconut of any variants. Coconut previously unmatched for red soil is also planted on red soil. Indeed, coconut risks from unfertile on red soil. Purplish tuber is planted again after harvest by stabbing new stem. Such way of planting also prevails for cassava and sweet potato.

(Focussed Group Discussion in Tnyafar Kora, Saturday, 11 June 2017)

In Tnyafar Nifmas, the strategy developed must always be matched with climate condition. The following explanation describes the importance of climate in determination of livelihood strategy.

When east wind is about to arrive at December to January, it benefits farmers by giving them a sign of rain season. It is time for farming. After 
February to March, farmers go to the sea. When they do farming, no one go sailing.

We obtain income only from sea grass when Sasi is opened. Now, the price goes down but few months later, it becomes IDR 5,000. We get the money from selling coconut, fried corn, cassava foliage, tomato, and chili. For regular income, we trade our commodities in Saumlaki Market. If the sale is good, we may go home in less than 3 days, but if the sale is not running out, we hold out for a week. We sleep in the market to guard our commodities. We go home with ketinting.

(Depth Interview with Mrs MF in Tnyafar Nimas, Thursday, 23 June 2017)

The effect of climate is described by one member of Tnyafar Wetyanan as following:

Corn is put aside in October to November. We harvest sweet potato on June to July and cultivate it again around February. If the harvested sweet potato is plenty, some are sold while others are consumed after burning them on mandekar (stone stove). Now, coconut is still subjected to Sasi. If some coconut fruits are falling, it is not allowed to take them for consumption. Washing the cloth is done before or after working on the garden. Planting activity is done during rain season because soil is more fertile in this climate.

(Depth Interview with Mrs ML in Tnyafar Wetyanan, Wednesday, 29 June 2017)

Farmers apply some strategies to process harvest into other derivative products. Members of Tnyafar Nifmas do such thing as shown in the following.

Corn, petatas, edible tuber, cassava, and banana are planted in Arin. Harvest is consumed, or shared with the less advantageous family because their garden is not producing, and the rest is sold. Sea grass is a main source of income, but the harvest from Arin is useful as a substitute in the case of failed sea grass, or is stored for household food reserve. Fried corn is sold to Adaut and Saumlaki Markets. Adaut Market is located in Saumlaki Area (in the middle of fish market). Adaut mothers sell the commodities in there. Harvest, mainly corn, is processed into dried corn (or fried corn). The preparation of fried corn starts with mixing corn with peanut and then pounding them with red bean. The batter is then fried. The pounded corn without frying is priced for IDR 10,000 per $\mathrm{kg}$. The fried corn in small cup of water is priced for IDR 5,000. A bottle of fried corn is priced at IDR 10,000 . Sometimes, husband accompanies wife to go selling to Saumlaki. Some mothers go together to Saumlaki because they can share fuel cost.

(Depth Interview with Mrs A in Tnyafar Nifmas, Friday, 1 July 2017)

All informations above indicate that every household is free in selecting livelihood strategy.
However, in each Tnyafar, livelihood strategy of each household may be similar. This similarity is strong enough because interaction across individuals has led into the exchange of information about important livelihood source that is reliable to develop. Besides, such habit is inherited into generations, and each household tends to defend livelihood strategy they inherit from parent. Since the beginning, Tnyafar members are free to choose whether they stay in Tnyafar or move to other Tnyafar. The usual trend is that the household develops certain livelihood strategy by following Tnyafar which is dominant in such livelihood strategy. It means that there is a sense of togetherness not only in achieving success, but also in accepting the failure.

Activities in fishery sector, such as sea grass cultivation, are developed in Tnyafar Nifmas and Tnyafar Torimtubun. In Tnyafar Kora, crop commodities are dominant and it is cultivated to secure household food. Therefore, members of Tnyafar Kora who want to cultivate sea grass would administer themself into membership of Tnyafar Nifmas and Tnyafar Torimtubun. The position of both latter Tnyafar is very promising indeed for developing sea grass commodity. Therefore, the selection of livelihood strategy in Tnyafar is determined by a location (compatibility) and a sense of togetherness. Freedom that allows Tnyafar members to move to other Tnyafar has helped household to develop suitable livelihood strategy for each Tnyafar. Based on the review by Jiri, Mafongoya, Mubaya, \& Mafongoya (2016), it is proved that scientific estimation at certain condition may still fail in helping smallholders due to the lacking of access to the information. Often, there is a clash between scientific method and custom-based forecast. The forecast is often without challenge, and used as the guidance in selecting adaptation strategy although farmers still find difficulty to integrate their strategy with scientific knowledge.

\section{CONCLUSION}

Women in Tnyafar do not bother to wait for scientific information because their local wisdom has been able to help them in performing climatebased farming. They learn natural signs from which they can predict the arrival of rain season as the sign for planting period and also estimate the possibility of drought such that they prepare food reserve.

Each agriculture location has its own characteristic. By then, farming is managed to cultivate crops selected by farmers. It prevails also in Tnyafar. Different location of Tnyafar has led to the variety of selected livelihood strategies if each strategy is not so much different after all. Almost all Tnyafar members are working in the agriculture sector, and 
therefore, the selection of commodities may determine the difference or even similarity of Tnyafar. In general, most Tnyafar cultivate crop commodities such as tubers, corn and rice. Some Tnyafar are not managed for rice because land condition in those Tnyafar may not be suitable for rice. Tubers are the main source of food and mostly found in all Tnyafar. What commodity is to cultivate always depends on the size of land.

\section{REFERENCES}

[1] Mardyaningsih Dyah Ita, Arya Hadi Dharmawan, Fredian Tonny. 2010. Dinamika Sistem Penghidupan Masyarakat Tani Tradisional dan Modern di Jawa Barat. Sodality [internet]. [diunduh 8 Oktober 2014]; 04 (01) : 115-145. Dapat diunduh pada http://journal.ipb.ac.id/index.php/sodality/article/ download $/ 5850 / 4515$

[2] Slamet, Widodo., 2012. Penguatan Modal Sosial Untuk Pengembangan Nafkah Berkelanjutan dan Berkeadilan. Prosiding Seminar Nasional Membangun Negara Agraris yang Berkeadilan dan Berbasis Kearifan Lokal. Penerbit Penguatan Modal Sosial Untuk Pengembangan Nafkah Berkelanjutan dan Berkeadilan Faperta UNS Surakarta.

[3] Yulianto E. H. 2013. Konservasi tradisional berbasis kearifan lokal masyarakat tani Kabupaten Paser (studi kasus Desa Semuntai Kecamatan Long Ikis Kabupaten Paser). Agrifor [internet]. [diunduh 8 Oktober 2014]; 07 (02) : 140-147. Dapat diunduh pada http://ejurnal.untagsmd.ac.id/index.php/AG/articl e/view/343

[4] Obayelu, Oluwakemi Adeola And Olufunke Rachael Orosile., 2015. Rural Livelihood and Food Poverty in Ekiti State, Nigeria., Journal of Agriculture and Environment for International Development - JAEID 2015, 109 (2):307-323, DOI: $10.12895 /$ jaeid.20152.373

[5] Chanamuto, Nicola J.C. \& Stephen J.G. Hall., 2015. Gender equality, resilience to climate change, and the design of livestock projects for rural livelihoods. Journal Gender_\& Development, Volume 23, 2015 - Issue 3: Resilience Pages 515-530 | Published online: 13 Nov 2015

[6] Mukoni, Manuku., 2015. Traditional Gender Roles of Men and Women in Natural Resource Conservation among the Vhavenda People in Zimbabwe: Implications for Sustainable Development. International Journal of Humanities and Social Science Vol. 5, No. 4 (1); April 2015
[7] Perz, Stephen G.L, 2015. The Importance of Household Asset Diversity for Livelihood Diversity and Welfare among Small Farm Colonists in the Amazon. The Journal of Development Studies, Vol.41, No.7, October 2005, pp.1193 - 1220., ISSN 0022-0388 print/1743-9140 online., DOI: 10.1080/00220380500170899

[8] BPS., 1990. Indonesia dalam Angka. BPS Jakarta.

[9] BPS., 2000. Indonesia dalam Angka. BPS Jakarta

[10] BPS., 2010. Indonesia dalam Angka. BPS Jakarta

[11] Arafura Timor Seas Ecosystem Action Programme., 2011., Masyarakat Pesisir di Kabupaten Maluku Tenggara Barat. Atsea.

[14] Pattiselanno, A.E, E. Jambormias, S.F.W. Thenu, S. Leimaheriwa, H. Amanupunyo, I.P. Siwa, dan J.D. Putuhena., 2015. Blue Print Pertanian Kabupaten MTB (Kerjasama Jurusan Agribisnis Fakultas Pertanian Unpatti dan Dinas Pertanian Kabupaten MTB). Penerbit Kanisius Jogyakarta.

[15] Yin, Robert. K., 1996. Studi Kasus (Desain dan Metode, Alih Bahasa : M.D. Mudzakir). Raja Grafindo Persada, Jakarta.

[16] Stake, Robert, E., 1995. The Art of Case Study. Sage Publications London New Delhi.

[17] Bogdan, R.C and Biklen, S.K., 1982. Methods of Social Research. Boston : Allyn and Bacon Inc.

[18] Creswell, John, 1994. Research Design, Qualitative and Quantitative Approach. London : Sage Publications.

[19] Moleong. L.J. 1989. Metodologi Penelitian Kualitatif. Bandung, Remaja Rosda Karya.

[20] Miles, Matthew, B dan A.M. Huberman., 1992. Analisis Data Kualitatif : Buku Sember Tentang Metode-Metode Baru. UI Press, Jakarta. 